\title{
NEW DATA CONCERNING THE DISTRIBUTION OF PSEUDOSCORPIONS IN ALBANIA (PSEUDOSCORPIONES: CHERNETIDAE)
}

\author{
Jana Christophoryová* \& Daniel Jablonski \\ Department of Zoology, Faculty of Natural Sciences, Comenius University, Mlynská dolina, \\ Ilkovičova 6, SK-842 15 Bratislava, Slovakia
}

Christophoryová, J. \& Jablonski, D.: New data concerning the distribution of pseudoscorpions in Albania (Pseudoscorpiones: Chernetidae). Vol. 26, No. 1., 117-122, 2017, Zagreb.

The chernetid pseudoscorpions Pselaphochernes lacertosus (L. Koch, 1873) and P. scorpioides (Herma$\mathrm{nn}, 1804)$ are here recorded for the first time from Albania and the second locality of the species Dendrochernes cyrneus (L. Koch, 1873) is reported.

Key words: Balkans, compost, new records, Pselaphochernes, Pseudoscorpiones, tree bark

Christophoryová, J. \& Jablonski, D.: Novi podaci o rasprostranjenosti pseudoškorpiona u Albaniji (Pseudoscorpiones: Chernetidae). Vol. 26, No. 1., 117-122, 2017, Zagreb.

Pseudoškorpioni iz porodice Chernetidae Pselaphochernes lacertosus (L. Koch, 1873) i P. scorpioides (Hermann, 1804) zabilježeni su prvi puta za Albaniju, a rad donosi i drugi lokalitet za vrstu Dendrochernes cyrneus (L. Koch, 1873).

Ključne riječi: Balkan, kompost, novi nalaz, Pselaphochernes, Pseudoscorpiones, kora drveta

\section{INTRODUCTION}

The family Chernetidae is a highly diverse group with over 650 species in more than 110 genera (HARver, 2013). They are found all over the world, occurring in a variety of habitats; i.e. under tree bark, in leaf litter, compost heaps or even in caves (BEIER, 1963; Harvey, 2013). However, it is noticeable that there is a low diversity of these species across the Balkans; the number of recorded species in the Balkan countries varies between 2 and 12 (for review see Tab. 1). The species are undervalued, for two reasons: (i) the main focus of attention in pseudoscorpion research is on soil species, mainly of the families of Chthoniidae and Neobisiidae; (ii) there is a lack of researchers dealing with pseudoscorpions in general. A low number of recorded species in some countries can be attributed to the fact that chernetids and their habitats have not yet been investigated in detail there.

Albania is a small country in southeast Europe with the high geomorphological, terrain and climate variability that has historically led to rich biological diversity. Basic zoological research into many invertebrates has only recently been initiated here, due to political and scientific isolation of the country. This is precisely the situation of the pseudoscorpions. Currently, only 20 pseudoscorpion species are known, belonging to five families (Harvey, 2013; Christophoryoví et al., 2017). From the family of Chernetidae the occurrence of only three species has been recorded - Dendrochernes cyrneus (L. 
Koch, 1873), Lasiochernes graecus Beier, 1963 and Lamprochernes nodosus (Schrank, 1803) (Beier, 1929, 1963; Christophoryoví et al., 2017). The aim of this study is to update information about the presence and occurrence of chernetids in Albania.

\section{MATERIAL AND METHODS}

During two excursions to Albania, 13 specimens of three chernetid species were collected. The body and dissected appendages of specimens were studied as temporary slide mounts using lactic acid, and subsequently returned to $70 \%$ ethanol. Measurements were taken from photographs using the Zeiss AxioVision 40LE application (v. 4.6). They were photographed using a Leica DM1000 compound microscope with ICC50 Camera Module (LAS EZ application, 1.8.0). The first author of the paper identified the specimens using identification keys in BeIER (1963) and Christophoryoví et al. (2011). The measurements taken follow BEIER (1963) and the nomenclature for taxa follows HARveY (2013). The material is deposited in the zoological collections of the first author in the Department of Zoology, Comenius University in Bratislava. The present paper also contains the published records of all known chernetid species from Albania. There was an effort to complete the faunistic data missing from the published records. The coordinates of sampling localities of other researchers are approximate and indicate the location within the territory of Albania.

\section{RESULT AND DISCUSSION}

\section{Dendrochernes cyrneus (L. Koch, 1873) (Figs. 1, 2A, 2D)}

Published record (BeIER, 1929): three adults phoretic on Asemum striatum (Linnaeus, 1758) (Coleoptera, Cerambicidae) at Mt. Gjallica e Lumës $\left(42.024^{\circ} \mathrm{N}, 20.509^{\circ} \mathrm{E} ; 1200 \mathrm{~m}\right.$ a. s. 1.; June 14, 1918).

Present record: one male collected under Pinus nigra Arnold bark in subalpine pine forest at Llogarë Pass (40.195 N, 19.598 E; 1028 m a. s. 1.; April 27, 2016).

BEIER (1929) did not mention the type of environment in which the specimens were collected. Our record represents the second known locality of the species in Albania. In the Balkans, the species is known from Bulgaria, Croatia and Romania (HARveY, 2013).

\section{Lamprochernes nodosus (Schrank, 1803) (Fig. 1)}

Published record (Christophoryová et al., 2017): one female extracted from a compost heap near the field at Uznovë $\left(40.685^{\circ} \mathrm{N}, 20.010^{\circ} \mathrm{E} ; 59 \mathrm{~m}\right.$ a. s. 1.; September 24, 2015).

In the Balkans, the species L. nodosus is known from Bulgaria, Greece and Romania (HARveY, 2013).

\section{Lasiochernes graecus Beier, 1963 (Fig. 1)}

Museum data: 23 specimens (party fragmented and including juveniles) found in the Meshgoranit cave $\left(40.319^{\circ} \mathrm{N}, 20.094^{\circ} \mathrm{E} ; 850 \mathrm{~m}\right.$ a. s. 1.; July 17, 1956).

BEIER $(1963,1965)$ described the species and mentioned a precise locality in Greece, but there are no faunistic data about specimens from Albania. With the help of Christoph Hörweg from the Museum of Natural History, Vienna we have found the missing data, such as specimen number, precise locality in Albania and sampling date. 


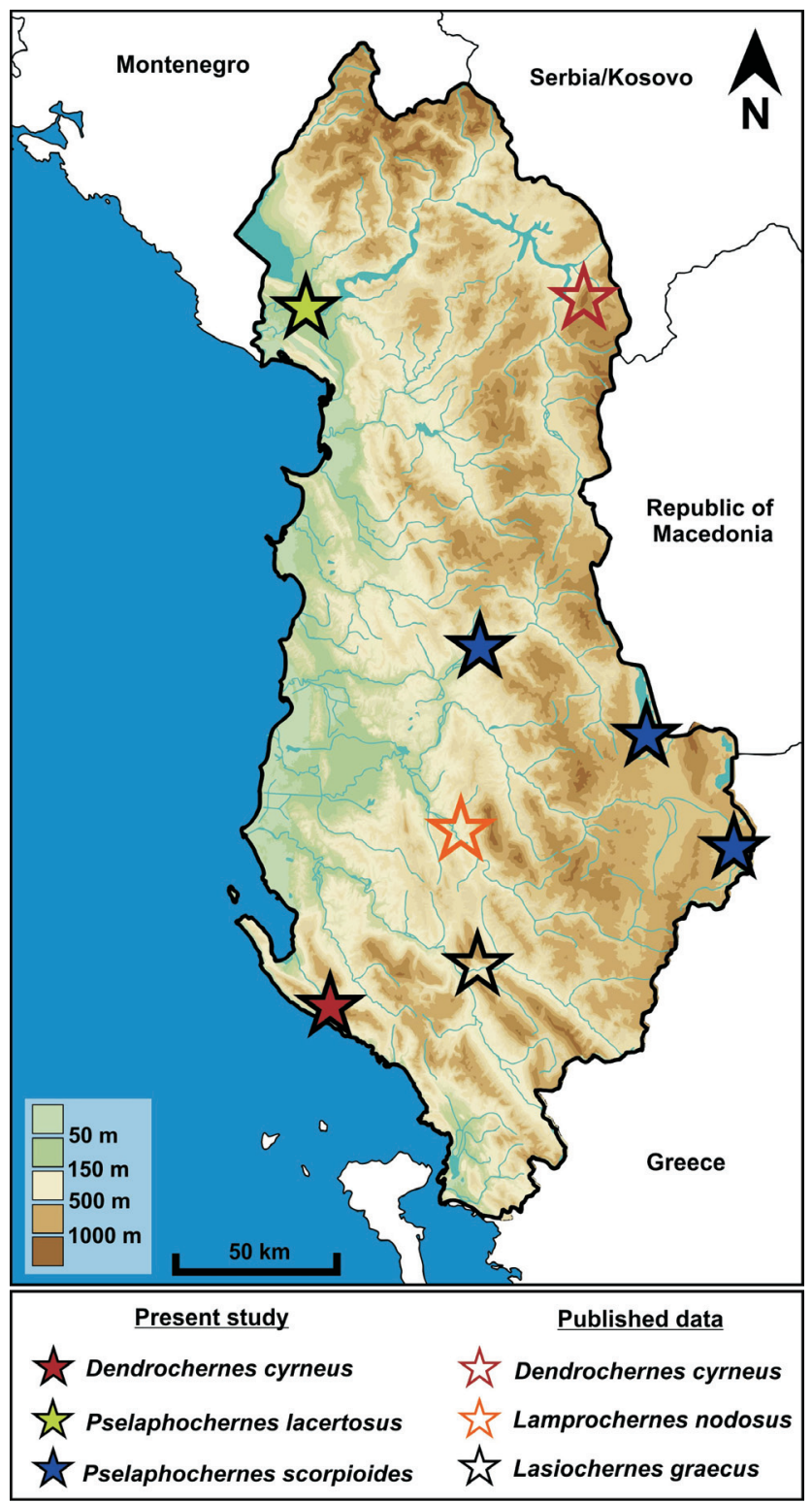

Fig. 1. Map of Albania showing published and the authors' records of chernetid species.

\section{Pselaphochernes lacertosus (L. Koch, 1873) (Figs 1, 2B, 2E)}

Present record: one male, sieved from a compost heap on the edge of the road at Bërdicë $\left(42.008^{\circ} \mathrm{N}, 19.480^{\circ} \mathrm{E} ; 7 \mathrm{~m}\right.$ a. s. 1.; September 27, 2016).

Harvey (2013) listed Bosnia and Herzegovina, Bulgaria and Greece among the countries of the Balkans where the species was recorded. Our finding represents the first record of the genus Pselaphochernes for Albania. Only one male was identified from 
Tab. 1. Species number of recorded pseudoscorpion genus of family Chernetidae in the Balkans (Harvey, 2013; Christophoryová et al., 2017). Abbreviations: AL - Albania, BA Bosnia and Herzegovina, BG - Bulgaria, HR - Croatia, GR - Greece, MK - Republic of Macedonia, ME - Montenegro, RO - Romania, RS/XK - Serbia/Kosovo, SI - Slovenia.

\begin{tabular}{|l|c|c|c|c|c|c|c|c|c|c|}
\hline Genus/ Country & AL & BA & BG & HR & GR & MK & ME & RO & RS/XK & SI \\
\hline Allochernes Beier, 1932 & & 1 & 2 & 1 & 2 & 1 & & 1 & 1 & \\
\hline Chernes Menge, 1855 & & & 3 & 1 & 3 & 1 & 1 & 1 & 1 & 2 \\
\hline Dendrochernes Beier, 1932 & 1 & & 1 & 1 & & & & 1 & & \\
\hline Dinocheirus Chamberlin, 1929 & & 1 & 1 & 1 & & & & & & 1 \\
\hline Lamprochernes Tömösváry, 1882 & 1 & & 2 & 1 & 2 & & 1 & 2 & 1 & \\
\hline Lasiochernes Beier, 1932 & 1 & & & & 3 & & & & & \\
\hline Pselaphochernes Beier, 1957 & & 2 & 3 & 1 & 2 & & & 1 & & \\
\hline Total & 3 & 4 & 12 & 6 & 12 & 2 & 2 & 6 & 3 & 3 \\
\hline
\end{tabular}

Tab. 2. Measurements of palpal segments of recorded Pselaphochernes species from Albania. Values of all the measured characters are in $\mathrm{mm}$. Abbreviations: $\mathrm{n}$ : number of measured specimens.

\begin{tabular}{|l|c|c|c|}
\hline Characteristics/ species, sex (n) & P. lacertosus & P. scorpioides & P. scorpioides \\
\hline Femur, length & male (1) & male (2) & female (9) \\
\hline Femur, width & 0.62 & $0.44-0.47$ & $0.48-0.59$ \\
\hline Femur, length/width ratio & 0.27 & $0.18-0.19$ & $0.17-0.22$ \\
\hline Patella, length & 2.30 & $2.44-2.47$ & $2.27-2.95$ \\
\hline Patella, width & 0.60 & $0.45-0.46$ & $0.44-0.52$ \\
\hline Patella, length/width ratio & 0.29 & 0.20 & $0.20-0.24$ \\
\hline Hand with pedicel, length & 2.07 & $2.25-2.30$ & $2.09-2.36$ \\
\hline Hand without pedicel, length & 0.61 & $0.43-0.46$ & $0.41-0.56$ \\
\hline Hand, width & 0.52 & $0.37-0.40$ & $0.36-0.49$ \\
\hline Hand with pedicel, length/width ratio & 0.40 & $0.23-0.25$ & $0.25-0.32$ \\
\hline Finger, length & 1.53 & $1.84-1.87$ & $1.63-1.81$ \\
\hline Chela, length & 0.53 & 0.40 & $0.41-0.49$ \\
\hline Chela, length/hand width ratio & 1.06 & $0.81-0.84$ & $0.81-0.99$ \\
\hline
\end{tabular}

compost heaps. By contrast, from the same genus, 11 specimens of $P$. scorpioides were sieved from compost. The species differ from each other mainly in palpal measurements and shape of palpal segments (Tab. 2). The main taxonomic characters correspond with the descriptions in the identification key in BEIER (1963). 

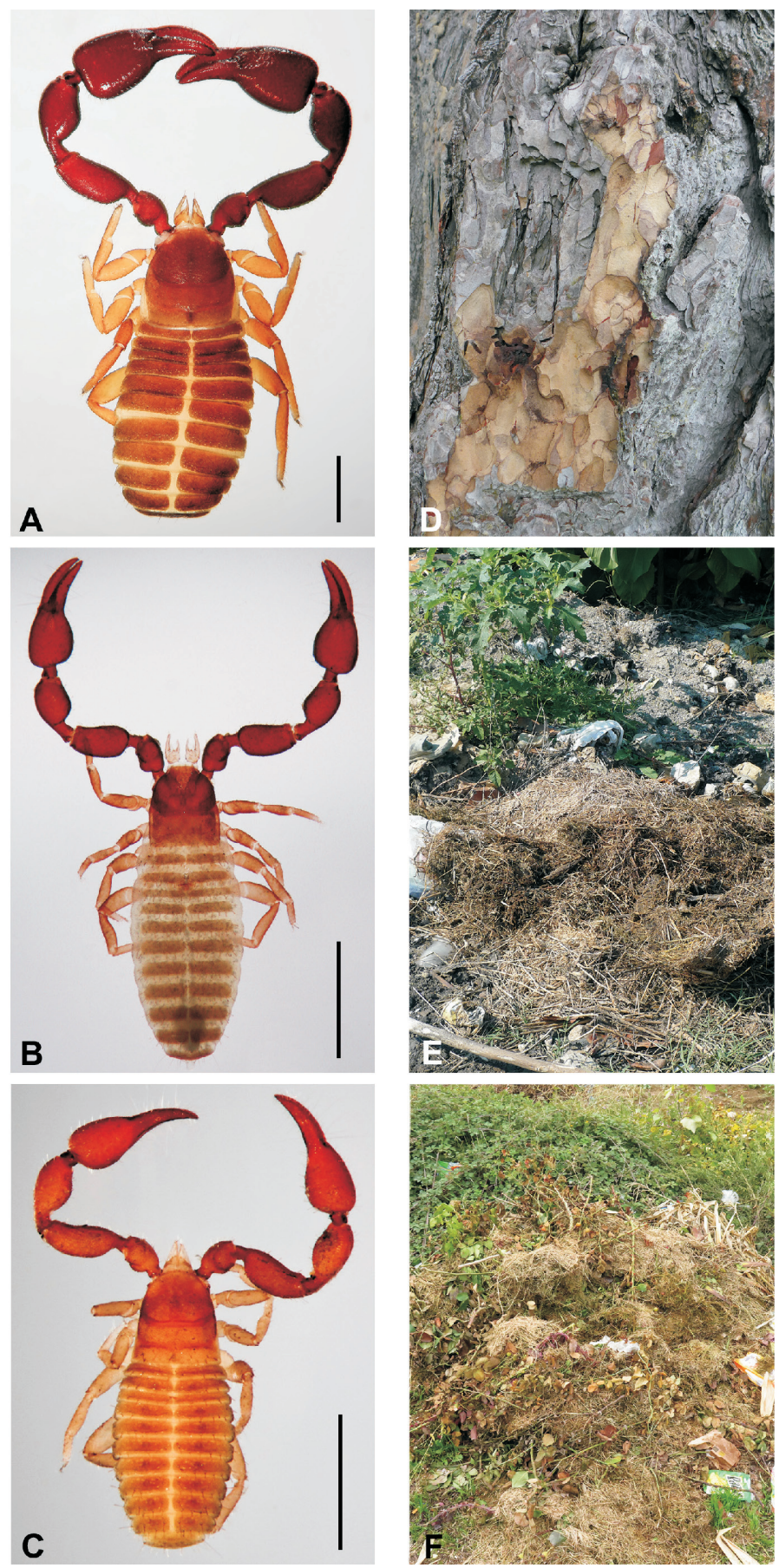

Fig. 2. Pseudoscorpions collected in Albania and their habitat types: (A) Dendrochernes cyrneus, (B) Pselaphochernes lacertosus, (C) P. scorpioides; (D) bark of Pinus nigra, (E, F) compost heaps. Scale lines for A - C: $1 \mathrm{~mm}$. 


\section{Pselaphochernes scorpioides (Hermann, 1804) (Figs. 1, 2C, 2F)}

Present records: seven females and one male sieved from a compost heap on the edge of the road at Pogradec $\left(40.898^{\circ}\right.$ N, $20.683^{\circ}$ E; 697 m a. s. 1.; September 27, 2015); one male and one female sievied from a compost heap at the edge of the road near the restaurant at Çibërraka $\left(41.159^{\circ} \mathrm{N}, 20.179^{\circ} ; 156 \mathrm{~m}\right.$ a. s. 1.; October 2, 2016); one female sieved from a compost heap in the village at Bilisht $\left(40.627^{\circ}, 20.996^{\circ} ; 957 \mathrm{~m}\right.$ a. s. 1.; October 3, 2016).

Measurements of palps for both sexes are given in Tab. 2. Regarding the Balkans, the species is known from Bulgaria, Greece and Romania (HARveY, 2013). Our findings represent the first record of the species for Albania.

\section{Acknowledgments}

We are very thankful to Christoph Hörweg (Museum of Natural History, Vienna, Austria) for helping with faunistic data about Dendrochernes cyrneus and Daniel Grula (Comenius University in Bratislava, Slovakia) for his technical assistance with Figure 2 and help during the fieldwork. We would like to thank Giulio Gardini and the second anonymous reviewer for all their corrections and comments that improved the manuscript. The study was financially supported by the project VEGA 1/0191/15.

Received January 19, 2017

\section{REFERENCES}

BeIER, M., 1929: Die Pseudoskorpione des Wiener Naturhistorischen Museums. II. Panctenodactyli. Annalen des Naturhistorischen Museums in Wien 43, 341-367.

BeIER, M., 1963: Ordnung Pseudoscorpionidea (Afterskorpione). Bestimmungsbücher zur Bodenfauna Europas. Vol. 1. Akademie-Verlag, Berlin.

BeIER, M., 1965: Pseudoscorpione aus ostmediterranen Grotten. Fragmenta Entomologica 4, 85-90.

Christophoryová, J., Grul'a, D. \& Jablonski, D., 2017: First record of the genus Lamprochernes (Pseudoscorpiones: Chernetidae) in Albania. Biharean Biologist, 11(1):62-64.

Christophoryová, J., ŠŤÁhlavskx́, F. \& Fedor, P., 2011: An updated identification key to the pseudoscorpions (Arachnida: Pseudoscorpiones) of the Czech Republic and Slovakia. Zootaxa 2876, 35-48.

Harvey, M. S., 2013: Pseudoscorpions of the World. Version 3.0. Western Australian Museum, Perth. Available from: http://museum.wa.gov.au/catalogues-beta/pseudoscorpions/ (Accessed at: 2017.01.15) 